\title{
In-vitro cytotoxicity and apoptosis mechanism of ethyl acetate extract from Trichoderma reesei strain TV221 associated with marine sponge: Stylissa flabelliformis
}

\author{
Erna Prawita Setyowati ${ }^{1,2^{*}}$, Sylvia Utami Tunjung Pratiwi ${ }^{1,2}$, Purwantiningsih ${ }^{1,3}$, Indah Purwantini ${ }^{1,2}$ \\ ${ }^{1}$ Faculty of Pharmacy, Gadjah Mada University, Yogyakarta, Indonesia. \\ ${ }^{2}$ Department of Pharmaceutical Biology, Faculty of Pharmacy, Gadjah Mada University, Yogyakarta, Indonesia. \\ ${ }^{3}$ Department of Pharmacology and Toxicology, Faculty of Pharmacy, Gadjah Mada University, Yogyakarta, Indonesia.
}

\begin{tabular}{l}
\hline ARTICLE INFO \\
\hline Article history: \\
Received on: $29 / 07 / 2018$ \\
Accepted on: $21 / 08 / 2018$ \\
Available online: $30 / 09 / 2018$
\end{tabular}

Key words:

Trichoderma reesei

strain TV221, cytotoxic

effect, apoptosis, Stylissa

flabelliformis, associated

sponge.

\begin{abstract}
This research aimed to acknowledge the cytotoxic effect of ethyl acetate extract fermented from Trichoderma reesei strain TV221 fungi associated with Stylissa flabelliformis sponge in various cell lines such as WiDr, T41, T47D, Raji, and Vero, as well as to discover the mechanism of cell's death. The result of fermented fungi T. reesei was extracted with ethyl acetate. Ethyl acetate extract was tested against cell lines using the MTT assay. The result of cytotoxic selectivity test with lowest IC50 price, then apoptosis test with double staining acridine orange-ethidium bromide method was performed Ethyl acetate extract fermented from T. reesei has cytotoxic ability against tumor cell lines (WiDr, T41, T47D, Raji) and is not toxic to normal cell lines (Vero). The test sample can spur apoptosis process on colon cancer cells Widr.
\end{abstract}

\section{INTRODUCTION}

Sponges are metazoan organisms that live attached to the seabed. Sponges are filter feeder. These organisms have many small pores on the surface of their bodies that allow water to enter and circulate through several channels in which microorganisms and organic particles are filtered and eaten (Hooper, 2004). Sponges have developed strong chemical defense mechanism to protect themselves from competitors and predators (Thoms and Schupp, 2006). Many researches have shown that secondary metabolites produced by sponges play a role in self-defense mechanism. It has the potential to be developed in treatment regarding antiviral, anticancer, and antimicrobial properties possessed by secondary metabolites of various sponges (Wang, 2006).

\section{"Corresponding Author}

Erna Prawita Setyowati, Department of Pharmaceutical Biology, Faculty of Pharmacy, Gadjah Mada University, Yogyakarta, Indonesia. E-mail:erna_prawita@ugm.ac.id
Data derived from National Cancer Institutes of the United States shows that sponges are a potential source of compounds in producing cytotoxic effects (Brinkman et al., 2017). Sponges are widely by-passed by sea water that contains certain compounds or microorganisms. The role of various microorganisms in sponges varies, such as a source of nutrients, and a symbiotic mutualism with the sponge itself. Symbiosis occurs when the sponge becomes a shelter for microbes. Microbes associated with sponge become food supplier (Proksch et al., 2002), stabilization of sponge structures, metabolic waste processors, and producers of sponge secondary metabolites (Thomas et al., 2010). So allegedly, microbe associated-sponges is the original producer of bioactive compounds found in sponges. This is also likely because sponges are the host for a large number of microorganism in which 50-60\% of its body mass consists of its associated microbes (Drzewiecka, 2016). Microbes associated with sponges can be bacteria, fungi, and microalgae (Taylor et al., 2007).

The development of compounds from sponges into 
drugs is constrained because of the difficulty in obtaining adequate and sustainable supplies from these compounds for preclinical and clinical studies (Kennedy et al., 2007). There is an increasing evidence that microbes associated with sponges may also act as the preferred source of biologically active compounds (Brinkman et al., 2017), for example, metabolites that have antimicrobial activity from the fermentation of Callyospongia aerizusa fungi associated with Callyospongia aerizusa sponges (Thomas et al., 2010). Eurotium cristatum fungi symbiont Mycale sp. sponge from Wonnapa Beach, Bangsaen, Chonburi Province, Thailand, has inhibitory activity on human tumor cell line, namely MCF-7 (breast adenocarcinoma), NCI-H460 (nonsmall cell lung cancer), and A375-C5 (melanoma) (Almeida et al., 2010). Sponges associated with microbes are known to be very specific in producing certain bioactive compounds, although the mutual mechanism between the hosts and associated microbes on compound production still needs further study (Thomas et al., 2010). An easier way to produce such active compounds on a bigger scale is to culture the hosts of microbes associated sponges (Thomas et al., 2010). Production of bioactive compounds through fermentation of associated fungi is a potential process for the industry as it is reproducible and able to be obtained by large amounts of filtrate.

This study is a continuation of the previous research (Setyowati et al., 2017; Setyowati et al., 2018) aimed at finding the active cytotoxic and antimicrobial compounds derived from Trichoderma reesei strain TV221 fungi associated with marine sponge Stylissa flabelliformis collected from West Bali National Park, Indonesia.

\section{MATERIALS AND METHOD}

\section{Materials}

Trichoderma reesei fungi associated with Stylissa flabelliformis sponge were taken from the waters of Menjangan Island, West Bali. Microbial tests used in the study were Escherichia coli (EC) ATCC 25922, Staphylococcus aureus (SA) ATCC 25923, Bacillus subtilis (BS) ATCC 6633, Enterococcus faecalis (EF) ATCC 29212, Candida albicans (CA) ATCC 10231 (Dexa). Sabouraud Dextrose Broth (SDB) (Oxoid), Nutrient Agar (NA) (Oxoid), Brain Heart Infusion (BHI) (Oxoid), breast cancer cells T47D, WiDr cells, 4T1 cells, and vero cells were sourced from the collection of Laboratorium Penelitian dan Pengujian Terpadu (LPPT) UGM, [3-(4,5-dimetiltetrazoliumbromide)] (MTT) (Sigma Aldrich), Phosphate Buffered Saline (PBS) (Sigma Aldrich), Roswell Park Memorial Institute (RPMI) 1640, Medium 199 (Sigma), Microplate 96 (IWAKI), Fetal Bovine Serum (FBS) 10\% (Sigma), 0.25\% Trypsin-EDTA (Gibco, Invitrogen Canada), Sodium Dodecyl Sulfate (SDS) (Merck-Schuchardt, Germany) $10 \%$ in $0.01 \mathrm{~N} \mathrm{HCl}$, Penicillin-Streptomycin $2 \%$ (Gibco, Invitrogen Canada), Fungizone $0.5 \%$ (Gibco), Doxorubicin (Kalbe Farma).

\section{Equipment}

Cytotoxic Safety Cabinet $\left(\mathrm{ESCO}^{\circledR}\right.$, type cytoculture), Haemocytometer $\left(\right.$ Assistet $\left.{ }^{\circledR}\right)$, Microplate reader $\left(\right.$ Bio-Rad $^{\circledR}$, Japan), ELISA reader ((Elx Bio Tech $\left.^{\circledR}\right), \mathrm{CO}_{2}$ incubator (Heraeus ${ }^{\circledR}$, Germany), Vacuum evaporator $\left(\right.$ Heidolpoph $\left.^{\circledR}\right)$, inverted microscope (Olympus ${ }^{\circledR}$, Japan).

\section{Cultivation and extraction of fungal secondary metabolite}

The fermentation method and fungi extraction of $T$. reesei strain TV221 associated with $S$. flabelliformis sponge were performed according to the method performed by Setyowati et al. (2017). For the production of secondary metabolites, the fungi were cultivated at $25^{\circ} \mathrm{C}$ for 11 days on saboroud dextrose saline broth (Sabouraud Broth $40 \mathrm{~g}$, seawater $1000 \mathrm{~mL}$ ) on a rotary shaker $(120 \mathrm{rpm})$ at room temperature $\left(25^{\circ} \mathrm{C}\right)$. The cultures were lyophilized and extracted with ethyl acetate; the extractions were evaporated in a rotary evaporation at $60^{\circ} \mathrm{C}$ until dry.

\section{Antimicrobial activity experimentation}

The method used was a microdilution method of liquid to test microbes Staphylococcus aureus ATCC 25923, Escherichia coli ATCC 25922, Bacillus subtilisATCC 6633, Enterococcus faecalis ATCC 29212 and Candida albicans ATCC 10231. The inoculated bacteria in a liquid medium and in the corresponding $\mathrm{OD}_{600}$ were diluted with the medium until the final bacteria concentration in the well was approximately $5 \times 10^{5}$ cells $/ \mathrm{mL}$. Approximately, $50 \mu \mathrm{L}$ of the test solution and $50 \mu \mathrm{L}$ of microbes were incorporated into the wells and the same was performed with the solvent control and positive control. Negative control wells were filled with $50 \mu \mathrm{L}$ inoculum and $50 \mu \mathrm{L}$ media, media control wells were filled with $100 \mu \mathrm{L}$ media, while control compounds with $50 \mu \mathrm{L}$ of test solution and $50 \mu \mathrm{L}$ media. The microplate was then incubated for 24 hours at $37^{\circ} \mathrm{C}$. Percent of inhibition was calculated by measuring the absorbance of the solution in the plate using a microplate reader at the $595 \mathrm{~nm}$ wavelength (CLSI, 2006).

\section{Experimentation of cytotoxicity on tumor cell lines (WiDr, T47D, T41, Raji) and normal cell line (Vero)}

Cell concentration of $2 \times 10^{4}$ cells was added into 96 well-plate wells. The plates were incubated for 24 hours in a $\mathrm{CO}_{2}$ incubator at $37^{\circ} \mathrm{C}$. After incubation, the medium was removed and washed using PBS of $100 \mu \mathrm{L} /$ wells. The samples at various concentration and control series were put into 96 wellplates at $100 \mu \mathrm{L} /$ wells. It was then re-incubated for 24 hours in a $\mathrm{CO}_{2}$ incubator at $37^{\circ} \mathrm{C}$. The samples and control samples were removed, the wells were then washed with PBS of $100 \mu \mathrm{L} /$ wells then the wells were added with $100 \mu \mathrm{L} /$ wells of MTT solution and incubated for 4 hours in a $\mathrm{CO}_{2}$ incubator at $37^{\circ} \mathrm{C}$. Formazan crystals formation was performed by checking the cell state using an inverted microscope. After the formazan crystals were formed, it was added with reagent SDS stopper at $100 \mu \mathrm{L} /$ wells and incubated in a dark incubator at room temperature.

Cell density was determined by absorbance readings using ELISA reader at $550 \mathrm{~nm}$ wavelength. Percentage of living cells was calculated using the following formula (CCRC, 2013):

$$
\text { Percentage of viable cells }=\frac{(\text { Abs sample }- \text { medium })}{\text { Abs normal }- \text { medium }} \times 100 \%
$$

Calculation of Selectivity Index (SI) (Badisa et al., 2009; Sutejo et al., 2016).

Selectivity was determined using the formula:

$$
\mathrm{SI}=\frac{\mathrm{IC}_{50} \text { on vero cells }}{\mathrm{IC}_{50} \text { on cancer cells }}
$$


$\mathrm{SI}=\mathrm{IC}_{50}$ of the sample in a normal cell line $/ \mathrm{IC}_{50}$ of the same sample in cancer cell line, where $\mathrm{IC}_{50}$ is the concentration required to kill $50 \%$ of the cell population. The extract is said to have high selectivity when the value is $\mathrm{SI} \geq 3$.

\section{Observation of apoptosis}

$2 \times 10^{4}$ cells $/ \mathrm{ml}$ of WiDR cells were plated on coverslips in a 24 to $50-60 \%$ confluent plate. After that, it was incubated with the test compound for 24 hours. The medium was removed and washed using Fetal Bovine Serum. Coverslips were taken and put on the glass slide before added with $10 \mu$ l acridine orangeethidium bromide and left for 15 minutes. It was then observed under the fluorescence microscope (Elmore, 2007).

\section{RESULT AND DISCUSSION}

In this research, the samples were made into series of concentration of $2000 ; 1000 ; 500 ; 400 ; 300 ; 250 ; 200 ; 150 ; 125$; $100 ; 75 ; 62,5 ; 50 ; 25 \mu \mathrm{g} / \mathrm{mL}$ and administered to cancer cells with an incubation time of 24 hours. This series of concentration was prepared by diluting the stock solution of the test samples with RPMI 1640 cell culture medium.

Cytotoxicity assays against T47D cells and Raji cells have been reported by Setyowati et al. (2017). The $\mathrm{IC}_{50}$ values obtained were 270 and $470 \mu \mathrm{g} / \mathrm{mL}$ respectively, therefore further treatment was performed on WiDr cells, 4T1 cells, and Vero cells as normal cell representatives.

The result of treatment of the test sample on WiDr cell was obtained by linear regression equation $y=-53.597 x+154.45$ with values of $r^{2} 0.7033$ and $r 0.8386$ (Figure 1e), and the result of treatment of the test sample on 4T1 cell was obtained by $\mathrm{y}=$ $-72.144 x+206.14$ with values of $r^{2} 0.7391$ and $r 0.8597$ (Figure $2 \mathrm{e})$. As seen from the $\mathrm{r}$ values obtained, the two tests have a linear relation between cell viability and the treatment of the test sample in various series of concentrations. From this linear regression, the value of $\mathrm{IC}_{50}$ can be calculated. The value of $\mathrm{IC}_{50}$ based on its test sample treatment on WiDr cell was $88.88 \mu \mathrm{g} / \mathrm{mL}$, while on the 4T1 cell was $145.98 \mu \mathrm{g} / \mathrm{mL}$.

The effect of cytotoxicity on test samples can also be observed in cell morphological changes in both WiDr cells and 4T1 cells. These cell morphological changes occurred along with the increase of test sample treatment dose. Cells underwent membrane blebbing with smaller cell size and more rounded shape. (Figure 1B, c, d in WiDr cell and Figure 2b, c, d in 4T1 cells) compared with the controls of WiDr and 4T1 cells (Figure 1a and Figure 2a).

In summary, the result of ethyl acetate extract of $T$. reese $i$ strain TV221 (EAFTrR) fungi experimentation can be seen in Figure 3. The $\mathrm{IC}_{50}$ values for natural ingredients extract had three levels of cytotoxicity classification; $\mathrm{IC}_{50}<10 \mu \mathrm{g} / \mathrm{mL}$ value means it has a very strong cytotoxic effect, $\mathrm{IC}_{50} 10-100 \mu \mathrm{g} / \mathrm{mL}$ means strong cytotoxicity, and $\mathrm{IC}_{50} 100-500 \mu \mathrm{g} / \mathrm{mL}$ means average cytotoxicity (Weerapreeyakul et al., 2012). As seen in Table 1, the reaction of (EAFTrR) experimentation on various cell lines resulted in lowest $\mathrm{IC}_{50}$ on WiDr cells with strong effect, therefore the death cell test mechanism (apoptosis) was only performed on WiDr cells.

The result of selectivity index measurement (Table 1) shows that EAFTrR is quite selective against tumor cell lines and may be developed further as a source of the anti-cancer compound.
Table 1: Selectivity index (SI) of cytotoxic activity of ethyl acetate extract of T. reesei strain TV221 fungi (EAFTrR) isolated from S. flabelliformis sponge.

\begin{tabular}{cccccc}
\hline \multirow{2}{*}{ No. } & Compound & \multicolumn{4}{c}{ Cell lines SI } \\
\cline { 3 - 6 } & WiDr Cells & 4T1 Cells & $\begin{array}{c}\text { T47D } \\
\text { Cells }\end{array}$ & $\begin{array}{c}\text { Raji } \\
\text { Cells }\end{array}$ \\
\hline 1 & EAFTrR & 27.3 & 16.6 & 9 & 5.17 \\
\hline
\end{tabular}

Note: selective when SI $>3$ (15).

\section{Apoptosis}

The process of programmed cell death, or apoptosis, is generally characterized by distinct morphological characteristics and energy-dependent biochemical mechanisms (Kennedy et al., 2007). Apoptosis occurs normally during development and aging and as a homeostatic mechanism to maintain cell populations in the tissue. Apoptosis also occurs as a defense mechanism such as in immune reactions or when cells are damaged by disease or noxious agents (Norbury and Hickson, 2001).

The above test sample cytotoxic data shows the presence of a cytotoxic effect. It can be shown by the phenomenon of cell line death caused by treatment of a test compound. Cell's death was caused by confirmatory test samples through an apoptotic mechanism. To determine whether the death of these WiDr cells went through an apoptotic mechanism, apoptosis test needs to be performed. Green fluorescent cells show living cells, while red fluorescent cells show dead cells. Red fluorescent whole cells show necrotic cells, while fragmented cells show apoptotic cells (Fink and Cookson, 2005).

The effect of the test sample on apoptotic induction on WiDr cells after 24 hours can be seen in Figure 3. Cells were stained with ethidium bromide-acridine orange, then observed using a fluorescence microscopy.

The cytotoxicity test was performed using MTT method with MTT substrate conversion parameter to formazan by succinic dehydrogenase enzyme. The cytotoxic test was performed on various cancer cells to determine the potency to delay the growth of various cells including normal cells due to the treatment of test samples. This experimentation was performed to determine the level of samples that can inhibit cell growth by up to $50 \%\left(\mathrm{IC}_{50}\right)$. Based on the cytotoxic test, $\mathrm{IC}_{50}$ test sample was found varies with the smallest in WiDr cells $(88.88 \mu \mathrm{g} / \mathrm{mL})$ and the largest in normal cells (which shows cell's toxicity on normal cells). On cell control, the condition of different cells if compared with cells with treatment can be seen. In addition to cells with treatment, the fragmentation of the cell nucleus which later became the body of apoptosis can also be seen.

The mechanism of inhibition of cancer cell growth may go by cell cycle arrest, cell cycle delay, or apoptotic mechanism. On apoptosis observation, the double straining method using ethidium bromide-acridine orange was performed. On the cell control, green fluorescence can be seen because it only absorbs acridine orange. Ethidium bromide cannot enter the cell control because cell integrity is still good (Dogan et al., 2015). In cells with test samples treatment at a concentration of $80 \mu \mathrm{g} / \mathrm{mL}$, most of the cells are fluoresced green and some fluoresced orange. It indicates the beginning of the loss of membrane permeability in the cells due to treatment on the samples. Consequently, ethidium bromide can enter the cells and cause orange fluorescence as an indicator of the cell's death. 


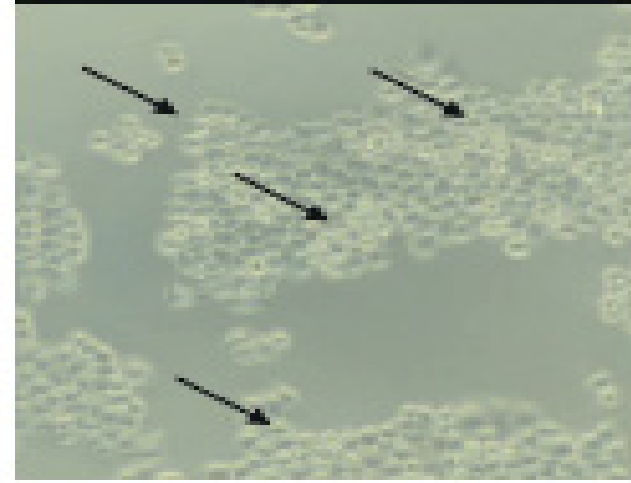

(a)

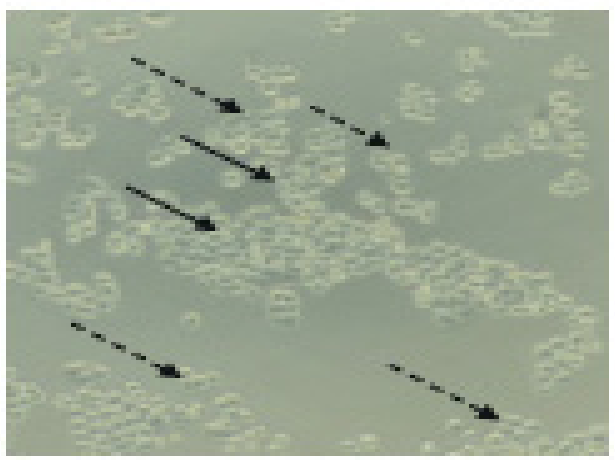

(b)

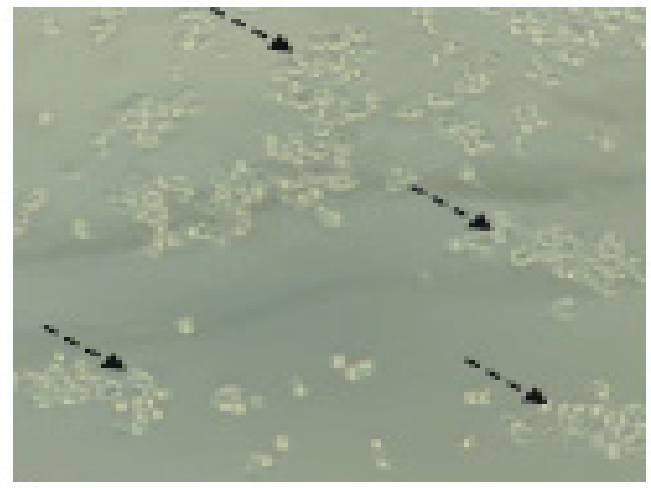

(c)

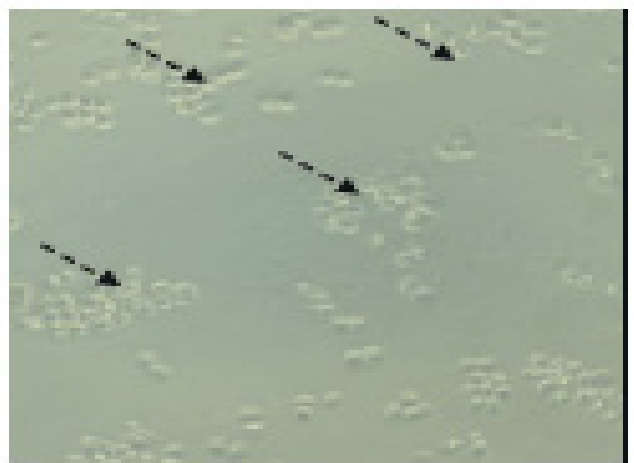

(d)

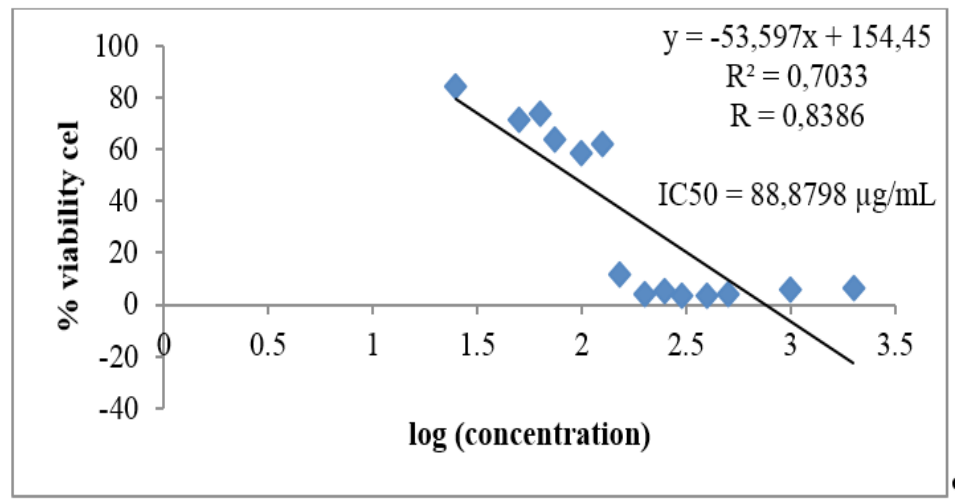

(e)

Fig. 1: The cytotoxic effect of the test sample on the viability of WiDr cells. The $10^{4}$ cell WiDr cell was planted on 96-well plate, then treated with the test sample for 24 hours. (A) Cell control morphology, (b) Treatment of ethyl acetate extract of Trichoderma reesei strain TV221 (EAFTrR) fungi with concentration of $25 \mu \mathrm{g} / \mathrm{mL}$, (c) $100 \mu \mathrm{g} / \mathrm{mL}$, (d) $2000 \mu \mathrm{g} / \mathrm{mL}$. The observation was performed under an inverted microscope with 100x magnification. The (solid arrow symbol) showed normal cells and (the dashed arrow symbol) signs of morphological changes. (e) Value of $\mathrm{IC}_{50}$ was obtained from a linear regression between concentration log vs $\%$ cell viability.

Apoptosis also occurs as a defense mechanism as in immune reaction or when cells are damaged by disease or harmful agents (Norbury and Hickson, 2001). Although there are various stimuli and conditions, both physiologically and pathologically that can trigger apoptosis, not all cells will always perish in a response to the same stimulus. Irradiation or drugs that are used for cancer chemotherapy result in DNA damage in some cells, which may cause apoptotic death through a pathway that depends on p53 (Dogan et al., 2015). Some hormones, like corticosteroid, may cause deadly apoptosis in some cells (e.g., thycomytes), although other cells are unaffected or even stimulated (Kennedy et al., 2007). In the WiDr cell, there is a p53 mutation at position 273 , and so there is a change of residual arginine into histidine. However, p21 in normal WiDr cells allows the cessation of cell cycles (Liu et al., 2006). Apoptosis in WiDr cells can occur through the independent pathway p53, including p73 activation. (Levrero et al., 2000). The results of this research indicate the potential of the test samples as anti-cancer genes because of the samples which are able to spur apoptosis. 


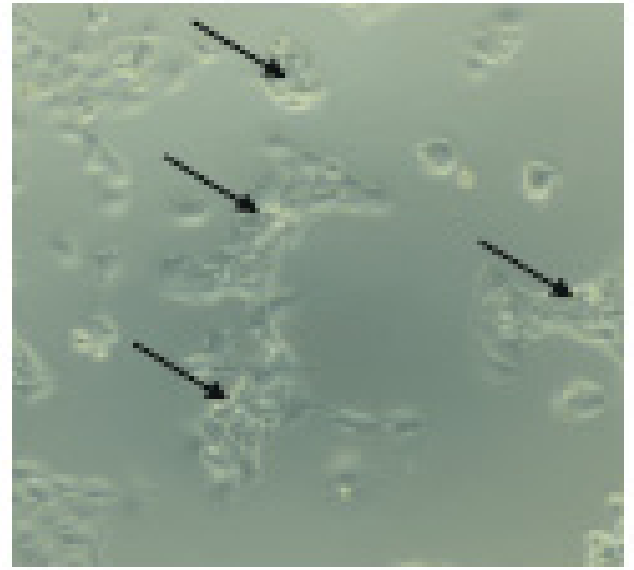

(a)

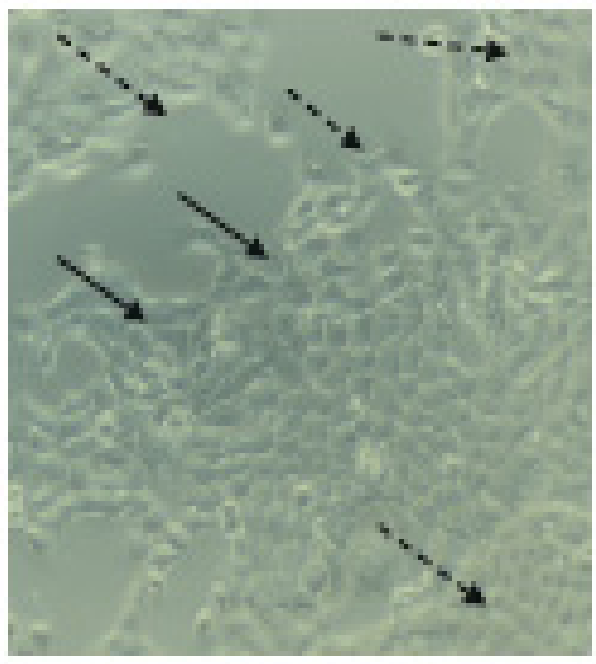

(b)

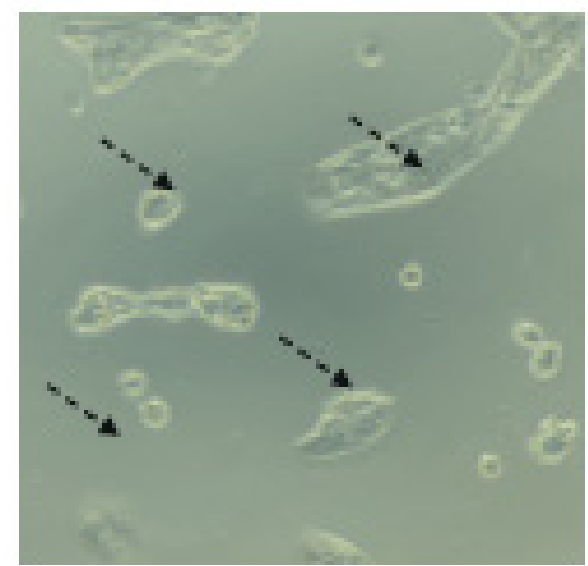

(c)

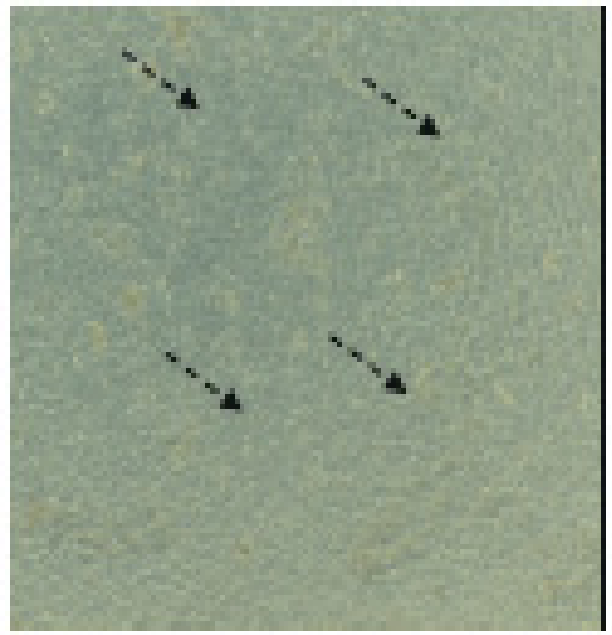

(d)

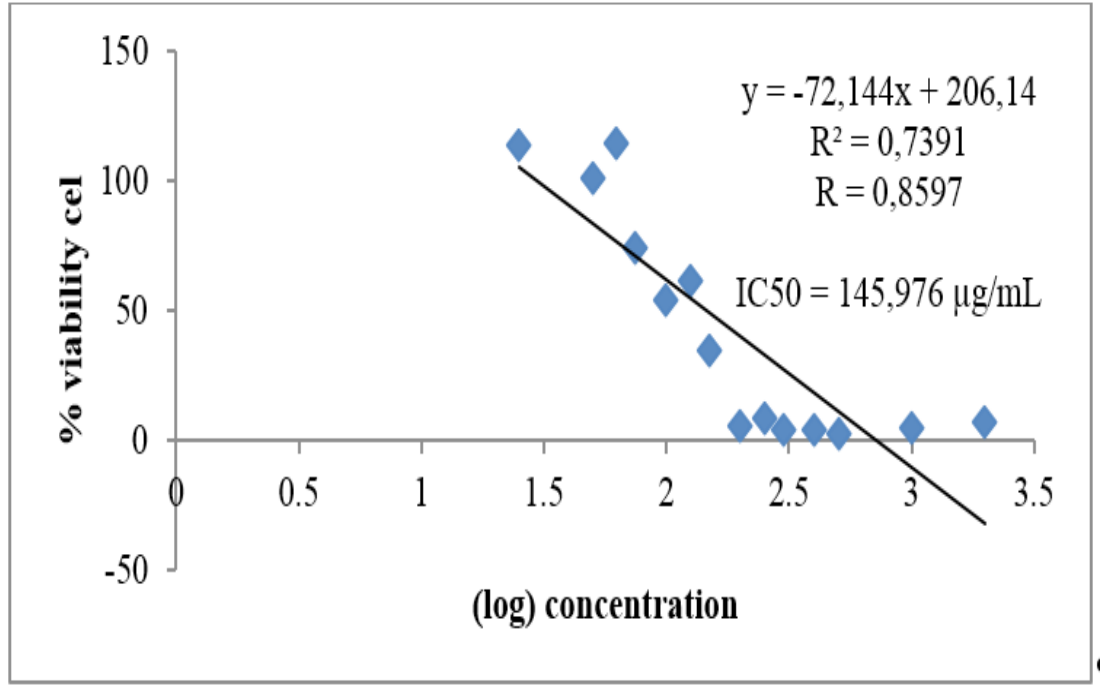

(e)

Fig. 2: Cytotoxic effect of the test sample on $4 \mathrm{~T} 1$ cell viability. As much as $10^{4}$ cells/wells of $4 \mathrm{~T} 1$ cells were planted on $96-$ well plate, then treated with the test sample for 24 hours. (A) Cell control morphology, (b) Treatment of ethyl acetate extract of Trichoderma reesei strain TV221 (EAFTrR) fungi with concentration of $25 \mu \mathrm{g} / \mathrm{mL}$, (c) $100 \mu \mathrm{g} / \mathrm{mL}$, (d) $2000 \mu \mathrm{g} / \mathrm{mL}$ The Observation was performed under inverted microscope with 100x magnification. The (solid arrow signs) showed normal cells and (the dashed arrow) morphological changes. (e) Value of $\mathrm{IC}_{50}$ was obtained from a linear regression between concentration $\log$ vs \% cell viability. 


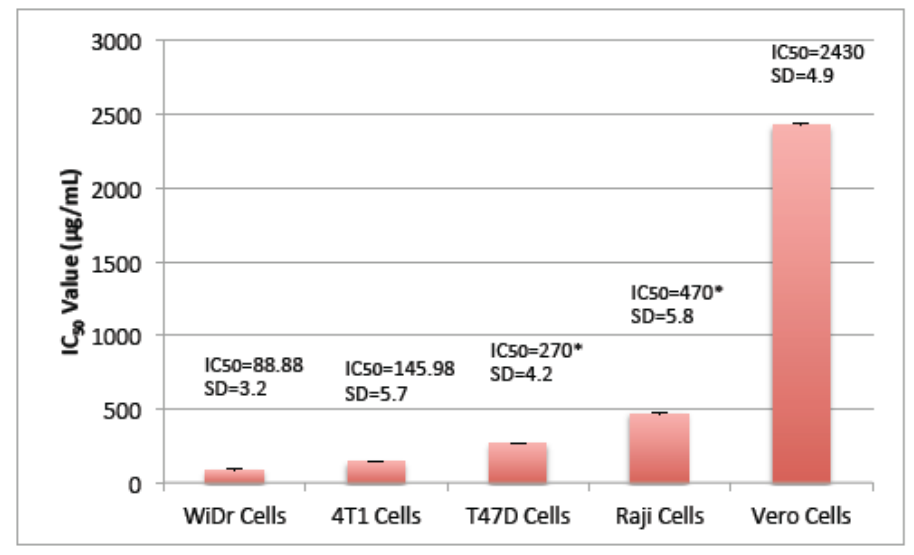

Fig. 3: Result of cytotoxic experimentation of ethyl acetate extract of T. reesei strain TV221 (EAFTrR) fungi. Note: *Setyowati et al. (2017), SD = standard deviation.

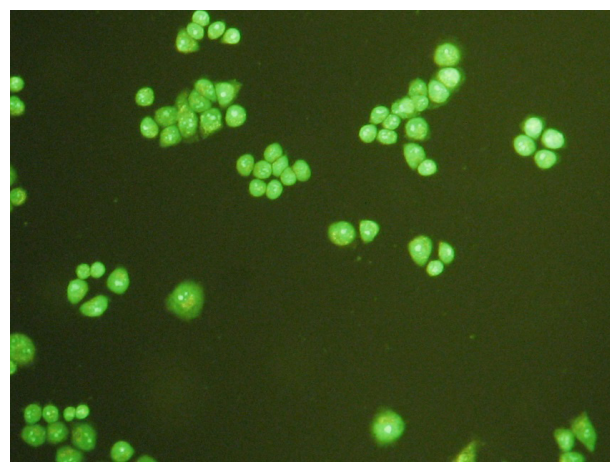

(a)

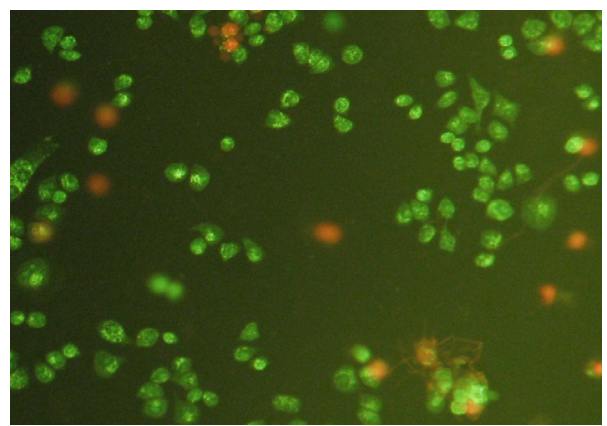

(c)

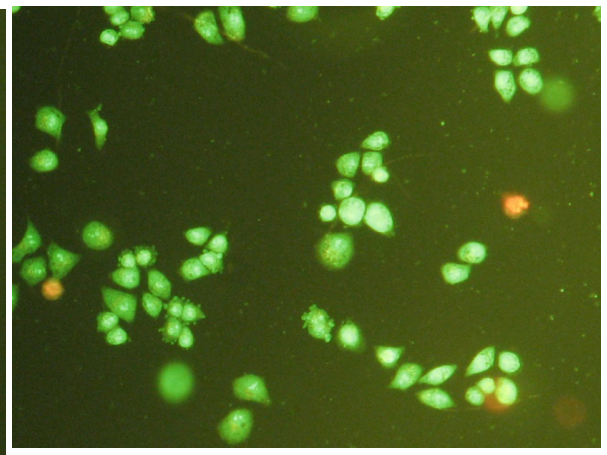

(b)

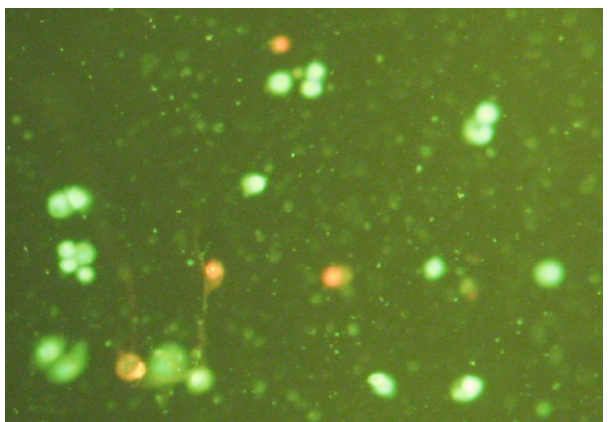

(d)

Fig. 4: Observation of apoptosis in fluorescence microscope with 40x magnification and 3x zoom out (a) Cell control, (b) $20 \mu \mathrm{g} / \mathrm{mL}$ concentration of test sample, (e) $40 \mu \mathrm{g} / \mathrm{mL}$ concentration, (d) $80 \mu \mathrm{g} / \mathrm{mL}$.

\section{CONCLUSION}

The extract of ethyl acetate from fermented fungi $T$. reesei TV221 strain has a cytotoxic effect on various tumor cell lines with a smallest $\mathrm{IC}_{50}$ value of $88.88 \mu \mathrm{g} / \mathrm{mL}$ in colon cancer cell Widr. The samples are selective towards all cell lines. The samples can spur apoptosis process on cancer cell Widr.

\section{ACKNOWLEDGMENT}

The author would like to acknowledge the funding support from PUPT-DIKTI Indonesia No: 184/UN1/DITLIT/DITLIT/LT/2018.

\section{SIGNIFICANCE STATEMENT}

This study was conducted to find microbes that associate with the sponge $S$. flabelliformis in an effort to produce compounds that have cytotoxic and antimicrobial activity.

\section{REFERENCES}

Almeida AP, Dethoup T, Singburaudon N, Lima R, Vasconcelos $\mathrm{MH}$, Pinto M, Kijjoa A. The in vitro anticancer activity of the crude extract of the sponge-associated fungus Eurotium cristatumand its secondary metabolites. Journal of Natural Pharmaceuticals, 2010; 1(1).

Badisa RB, Reed SFD, Josph P, Cooperhood JS, Latinwo LM, 
Goodman CB. Selective Cytotoxic Activities of Two Novel Synthetic Drugs on Human Breast Carcinoma MCF-7 Cells. Anticancer Res, 2009; 29(8):2993-2996.

Brinkman CM, Marker A, Kurtböke DI. An Overview on Marine Sponge-Symbiotic Bacteria as Unexhausted Sources for Natural Product Discovery, Diversity, 2017; 9(40).

CCRC. Cytotoxic test protocol with MTT assay, Faculty of Pharmacy, Universitas Gadjah Mada, Yogyakarta. 2013.

CLSI, Methods for Dilution Antimicrobial Susceptibility Test for Bacteria that Grow Aerobically; Approved Standard, $7^{\text {th }}$ Edition, Clinical and Laboratory Standards Institute, Wayne, Pensylvania. 2006.

Drzewiecka D. Significance and Roles of Proteus spp. Bacteria in Natural Environments. Microb Ecol, 2016; 72:741-758.

Elmore S. Apoptosis: A Review of Programmed Cell Death. Toxicol Pathol, 2007; 35(4):495-516.

Fink SL, Cookson BT. Apoptosis, Pyroptosis, and Necrosis: Mechanistic Description of Dead and Dying Eukaryotic Cells. Infect Immun, 2005; 73(4):1907-1916.

Hooper JNA, Sponguide: Guide to Sponge Collection and Identification, Queensland Museum, South Brisbane. 2004.

Kennedy J, Marchesi JR, Dobson ADW. Metagenomic Approaches to Exploit the Biotechnological Potential of the Microbial Consortia of Marine Sponges. Applied Microbiology and Biotechnology, 2007; 75(1):11-20.

Levrero M, De Laurenzi V, Constanzo A, Sabatini S, Gong J, Wang JYJ, Melino G. The p53/p63/p73 Family of Transcription Factors: Overlapping and Distinct Functions. Journal of Cell Science, 2000; 113:1661-1670

Liu HC, Chen GG, Vlantis AC, Leung BCS, Tong MCE, van Hasselt CA. 5-Fluorouracil Mediates Apoptosis and G1/S Arrest in Laryngeal Squamous Cell Carcinoma via a p53-Independent Pathway. The Cancer Journal, 2006; 12(6):482-49.

Norbury CJ, Hickson ID, Cellular responses to DNA damage. Annu Rev Pharmacol Toxicol, 2001; 41:367-401.

Proksch P, Edrada RA, Ebel R. Drugs from The Seas-Current Status and Microbiological Implications. Applied Microbiology and Biotechnology, 2002; 125-134.

Setyowati EP, Sudarsono dan Wahyuono S, Cytotoxicity and antimicrobial test of the bioactive compound isolated from Stylissa flabelliformis sponge. Indonesian Journal of Pharmacy, 2004, 15(2):50-56.

Setyowati EP, Sylvia UTP, Purwantiningsih, Samara O.
Bioactivity of Fungi Trichoderma reesei Associated with Sponges Stylissa flabelliformis Collected from National Park West Bali, Indonesia. Journal of Biological Sciences, 2017; 17(8):362-368.

Setyowati EP, Sylvia UTP, Purwantiningsih, Samirana PO. Antimicrobial activity and Identification of fungus associated Stylissa flabelliformis sponge collected from Menjangan Island West Bali National Park. Indonesia, Indonesian Journal of Pharmacy, 2018; 29(2):66-73.

Sutejo IR, Putri H, Meiyanto E. The Selectivity of Ethanolic Extract of Buah Makassar (Brucea javanica) on In vitro Study of Metastatic Breast Cancer. Journal of Agromedicine and Medical Sciences, 2016; 2(1):1-5.

Taylor MW, Radax R, Steger D, Wagner M. Sponge-Associated Microorganisms: Evolution, Ecology, and Biotechnological Potential. Microbiol Mol Biol Rev, 2007; 71(2):295-347.

Thomas TRA, Kavlekar DP, Lokabharathi PA. Marine Drugs from Sponge-Microbe Association - A Review. Marine Drugs, 2010, 8(4): $1417-146$.

Thoms C, Schupp PJ. Chemical defense strategies in sponges: a review, Porifera research: Biodiversity. Innovation and sustainability, 2006; 627-637.

Wang G. Diversity and biotechnological potential of the spongeassociated microbial consortia. Journal of Industrial Microbiology and Biotechnology, 2006; 33(7):545-551.

Weerapreeyakul N, Nonpunya A, Barusrux S, Thitimetharoch T, Sripanidkulchai B. Evaluation of the Anticancer Potential of the Six Herbs Againts a Hepatoma Cell Line. Chinese Medicine Journal, 2012; 7:15.

Dogan SM, Ercetin AP, Altun Z, Dursun D, Aktas S. Gene expression characteristic of breast cancer stem cell. JBUON, 2015; 20:1304-1313.

Ebad SS, Proksch P. Bioactive Secondary Metabolites from Marine Derived Fungi in Marine Pharmacognosy Trends and Applications edited by Se Kwon Kim. CRC, 2013; 27-52.

How to cite this article:

Setyowati EP, Pratiwi SUT, Purwantiningsih, Purwantini I. Invitro cytotoxicity and apoptosis mechanism of ethyl acetate extract from Trichoderma reesei strain TV221 associated with marine sponge: Stylissa flabelliformis. J App Pharm Sci, 2018; 8(09): 151-157. 